\title{
Sodium orthovanadate inhibits growth and triggers apoptosis of human anaplastic thyroid carcinoma cells in vitro and in vivo
}

\author{
QINGAN YU, WENJING JIANG, DAN LI, MINGQI GU, KUNPENG LIU, \\ LIQIAN DONG, CHAOQUN WANG, HONGCHI JIANG and WENJIE DAI \\ Department of General Surgery, The First Affiliated Hospital of Harbin Medical University, \\ Harbin, Heilongjiang 150001, P.R. China
}

Received May 3, 2018; Accepted December 17, 2018

DOI: $10.3892 / \mathrm{ol} .2019 .10090$

\begin{abstract}
Vanadium and its compounds exhibit concentration- and time-dependent anticancer effects on various types of tumor; however, the effects of sodium orthovanadate (SOV) on anaplastic thyroid carcinoma (ATC) have not yet been reported. In the present study, the anticancer effects of SOV on ATC were evaluated. In vitro experiments, including cell viability assays, plate colony formation assays, cell cycle analysis and apoptosis analysis were used to study the role of SOV in ATC. Using in vivo experiments, the effects of SOV on the growth and apoptosis of an ATC-xenograft tumor were studied by comparing the SOV-treatment with the control group. The results revealed that treatment of the human ATC cell line $8505 \mathrm{C}$ with SOV inhibited cell viability, induced $\mathrm{G}_{2} / \mathrm{M}$ phase cell cycle arrest, stimulated apoptosis and reduced mitochondrial membrane potential in a concentration-dependent manner. These findings were confirmed in vivo in a nude mouse ATC xenograft model. In conclusion, the present study demonstrated that SOV inhibited human ATC by regulating proliferation, cell cycle progression and apoptosis, thus suggesting that SOV may be considered a novel option for the treatment of ATC.
\end{abstract}

\section{Introduction}

Anaplastic thyroid carcinoma (ATC) is a highly invasive, undifferentiated tumor characterized by rapid growth and distant metastasis. ATC accounts for $<2 \%$ of all types of thyroid cancer, but is responsible for $>50 \%$ of cases of thyroid cancer-associated mortality (1-3). Half of all cases of ATC-associated mortality are caused by upper airway

Correspondence to: Professor Hongchi Jiang or Professor Wenjie Dai, Department of General Surgery, The First Affiliated Hospital of Harbin Medical University, 23 Youzheng Street, Harbin, Heilongjiang 150001, P.R. China

E-mail: jianghc2013@163.com

E-mail: davidhmu@163.com

Key words: sodium orthovanadate, anaplastic thyroid carcinoma, $8505 \mathrm{C}$ cells, tumor growth, apoptosis obstruction and asphyxia, whereas the remaining cases are attributed to local or distant metastases and/or treatment complications (4). The patient survival time after diagnosis is $\sim 16$ weeks, and the 1 and 5 year survival rates are 17 and $8 \%$, respectively (5). In addition, the available treatments for ATC, including surgery, radiotherapy and chemotherapy, have poor results (6). Therefore, the development of novel approaches is crucial, and may include novel cytotoxic drugs, targeted molecular therapies and gene therapies, in order to kill ATC cells (7-10).

Vanadium is a transition metal that belongs to the group of micronutrients that are essential for normal metabolism. Notably, sodium orthovanadate (SOV) is a vanadium compound and phosphate analog, which possesses numerous biological activities, including inhibition of nonselective protein tyrosine phosphatases, alkaline phosphatases and ATPases, activation of tyrosine kinases, promotion of mitogenesis and neuroprotection, and inhibition of diabetic effects by an insulin-mimetic property $(11,12)$. SOV can also inhibit the growth of central nervous system tumors (13), lung cancer (14), prostate cancer (15), bladder cancer (16) and liver cancer $(17,18)$. However, the effects of SOV on ATC cells have not yet been reported.

The present study aimed to investigate the effects of SOV on ATC in vitro and in vivo. To do so, the influence of SOV on cell growth, cell cycle progression, apoptosis and mitochondrial membrane potential $(\Delta \psi \mathrm{m})$ were investigated.

\section{Materials and methods}

Cell culture, reagents and antibodies. The human ATC cell line $8505 \mathrm{C}$ was kindly provided by Dr Jihua Han (The Third Affiliated Hospital of Harbin Medical University, Harbin, China). Cells were cultivated in RPMI 1640 medium supplemented with $10 \%$ fetal bovine serum and $1 \%$ penicillin/streptomycin at $37^{\circ} \mathrm{C}$ in a humidified incubator containing $5 \% \mathrm{CO}_{2}$. SOV was purchased from Sigma-Aldrich (Merck KGaA, Darmstadt, Germany). Antibodies against Ki-67 (catalog no. 9449S) were provided by Cell Signaling Technology, Inc. (Danvers, MA, USA).

Cell viability assay. Cell viability was assessed with the Cell Counting kit-8 (CCK-8; Dojindo Molecular Technologies, 
Inc., Kumamoto, Japan). Briefly, cells were cultured in 96-well plates with RPMI 1640 medium overnight prior to treatment with $\operatorname{SOV}(0,0.5,1,2,4$ and $8 \mu \mathrm{M})$ for 1-6 days and incubated at $37^{\circ} \mathrm{C}$. The cells were seeded between 500 and 3,000 cells/well, in $100 \mu 1$ culture medium, depending on the culture times tested (1-6 days). After the appropriate culture time, $10 \mu$ 1 CCK-8 solution was added to each well for $1 \mathrm{~h}$, prior to measuring the absorbance at $450 \mathrm{~nm}$ with a microplate reader. The half maximal inhibitory concentration $\left(\mathrm{IC}_{50}\right)$ values were calculated according to the Reed-Muench method (19). Experiments were performed three times.

Plate colony formation assay. Cells were seeded in 6-well plates at a density of 500 cells/well and incubated overnight at $37^{\circ} \mathrm{C}$. They were then treated with various concentrations of $\operatorname{SOV}(0,0.5,1,2,4$ and $8 \mu \mathrm{M})$ for 14 days and incubated at $37^{\circ} \mathrm{C}$. Each treatment was carried out in triplicate. Plates were incubated for 14 days. Medium containing the appropriate concentration of SOV was replaced twice weekly. Eventually, plates were washed twice with cold PBS, fixed with $4 \%$ paraformaldehyde for $10 \mathrm{~min}$, and stained with $3 \%$ crystal violet. Colonies containing $\geq 50$ cells were scored.

Cell cycle analysis. Cell cycle progression of $8505 \mathrm{C}$ cells was analyzed using a Cell Cycle kit (catalog no. 558662; BD Biosciences, San Jose, CA, USA). Briefly, following treatment with various concentrations of $\operatorname{SOV}(0,0.5,1,2,4$ and $8 \mu \mathrm{M})$ at $37^{\circ} \mathrm{C}$ for $48 \mathrm{~h}$, cells were harvested. A total of $1 \times 10^{6}$ cells were incubated with reagents $\mathrm{A}-\mathrm{C}$, according to the manufacturer's protocol, and cells were subjected to flow cytometry. Experiments were performed three times.

Apoptosis analysis. Cell apoptosis was analyzed with the fluorescein isothiocyanate (FITC)/Annexin V Apoptosis Detection kit I (BD Biosciences), according to the manufacturer's protocol. Briefly, cells were treated with various concentrations of $\operatorname{SOV}(0,2$ and $4 \mu \mathrm{M})$ and incubated at $37^{\circ} \mathrm{C}$ for $48 \mathrm{~h}$. Subsequently, cells were washed twice with cold PBS, resuspended in 1X Binding Buffer at a concentration of $1 \times 10^{6}$ cells $/ \mathrm{ml}$, and $100 \mu 1$ of each cell solution was transferred to individual $5 \mathrm{ml}$ culture tubes. A volume of $5 \mu \mathrm{l}$ FITC-conjugated Annexin V and $5 \mu$ l propidium iodide were added to the tubes, which were gently vortex-mixed, prior to 15 min incubation in the dark at room temperature. A volume of $400 \mu 1 \mathrm{X}$ Binding Buffer was then added to each tube. The samples were immediately analyzed by flow cytometry $(<1 \mathrm{~h})$. Experiments were performed three times.

$\Delta \psi m$ assessment. The lipophilic cationic dye $\mathrm{JC}-1$ was used to measure alterations in $\Delta \psi \mathrm{m}$. The JC-1 probe was provided by Beyotime Institute of Biotechnology (Haimen, China) and the assay was performed according to the manufacturer's protocol. Briefly, cells were incubated with SOV $(0,2$ and $4 \mu \mathrm{M})$ in 6-well plates at $37^{\circ} \mathrm{C}$ for $48 \mathrm{~h}$, prior to adding $5 \mu \mathrm{g} / \mathrm{ml} \mathrm{JC}-1$ for $20 \mathrm{~min}$ at $37^{\circ} \mathrm{C}$. After incubation with $\mathrm{JC}-1$, cells were washed twice with PBS. The $\Delta \psi \mathrm{m}$ was assessed by determining the dual emissions from mitochondrial JC-1 monomers (green, $490 \mathrm{~nm}$ stimulated luminescence and $530 \mathrm{~nm}$ emission light) and aggregates (red, $525 \mathrm{~nm}$ stimulated luminescence and $590 \mathrm{~nm}$ emission light) using a confocal laser scanning microscope. An increase in the green/red fluorescence intensity ratio indicated mitochondrial depolarization. The relative $\Delta \psi \mathrm{m}$ was calculated according to the following formula: Experimental ratio value/Control ratio value x100. Experiments were performed three times.

Xenograft tumor model and treatments. Female nude mice (5 weeks old; 16-18 g; Beijing Vital River Laboratories Animal Technology Co., Ltd., Beijing, China) were housed at a constant temperature $\left(23^{\circ} \mathrm{C}\right)$ and relative humidity $(60 \%)$ with a fixed 12-h light-dark cycle, and free access to food and water. After 1 week of feeding in the new environment, mice were then used to generate a subcutaneous tumor model. All surgical procedures and animal care protocols were approved by the Ethics Committee of the First Affiliated Hospital of Harbin Medical University (Harbin, China). The study also complied with institutional guidelines for animal care. An 8505C cell suspension $(100 \mu \mathrm{l})$ in serum-free RPMI 1640 culture medium $\left(1 \times 10^{6}\right)$ was subcutaneously injected into the flanks of nude mice. Tumor formation and tumor size were monitored daily. When tumors were $\sim 4 \mathrm{~mm}$ in diameter, animals were randomly divided into three groups, according to their similar average tumor sizes ( $\mathrm{n}=4 \mathrm{mice} / \mathrm{group}$ ). Mice received daily $200 \mu \mathrm{l}$ intraperitoneal injections of either PBS (control) or SOV (5 or $10 \mathrm{mg} / \mathrm{kg}$ ) in PBS. The doses and methods were based on our preliminary experiments and previous reports $(17,20)$. Tumor size was assessed twice weekly at the skin surface and calculated as follows: Tumor volume $=(\text { width })^{2} \mathrm{x}$ (length/2). After 4 weeks treatment, tumors were harvested, weighed and their volume was measured.

Detection of $8505 C$ cell proliferation in vivo. Immuno histochemical analyses of the tumors were performed using an anti-Ki-67 antibody, in order to detect cancer cell proliferation. Briefly, tumor paraffin sections $(4 \mu \mathrm{m})$ were prepared by fixation with $10 \%$ formaldehyde solution for $12 \mathrm{~h}$ at room temperature, washing with water for $24 \mathrm{~h}$, dehydration, transparency, embedding with paraffin, sectioning and baking for $30 \mathrm{~min}$ at $60^{\circ} \mathrm{C}$. Following dewaxing, rehydration and antigen retrieval, the tumor sections were blocked in $3 \%$ bovine serum albumin (catalog no. 37520; Thermo Fisher Scientific, Inc.) at room temperature for $2 \mathrm{~h}$, and incubated overnight at $4^{\circ} \mathrm{C}$ with primary antibody against Ki-67 (1:200; catalog no. 8112S; Cell Signaling Technology, Inc.). Sections were subsequently incubated at room temperature for 30 min with SignalStain ${ }^{\circledR}$ Boost Detection Reagent (HRP, Mouse) (catalog no. 8125S; Cell Signaling Technology, Inc.), then examined by light microscopy (magnification, x400).

Detection of apoptosis of 8505 C cells in vivo. Cell apoptosis was determined in situ with a terminal deoxynucleotidyl transferase dUTP nick-end labeling (TUNEL) cell apoptosis detection kit (Beyotime Institute of Biotechnology), according to the manufacturer's protocol. Briefly, $4 \mu \mathrm{m}$ tumor sections were dewaxed with xylene twice for $5 \mathrm{~min}$, and soaked in $100 \%$ ethanol for $5 \mathrm{~min}, 90 \%$ ethanol for $2 \mathrm{~min}$ and $70 \%$ ethanol for $2 \mathrm{~min}$. Sections were rinsed with distilled water for $2 \mathrm{~min}$ and incubated with $20 \mu \mathrm{g} / \mathrm{ml}$ proteinase $\mathrm{K}$ without DNase at $37^{\circ} \mathrm{C}$ for $15 \mathrm{~min}$. They were eventually washed three times with PBS, and exposed to $50 \mu 1$ TUNEL working fluid. 
A

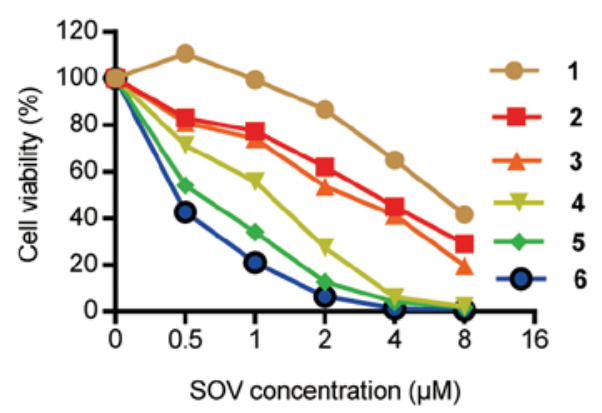

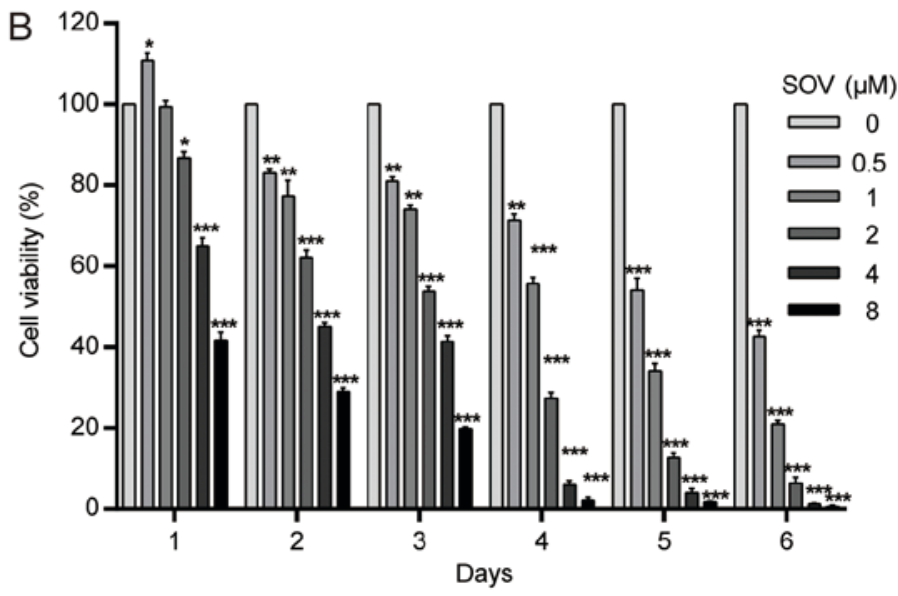
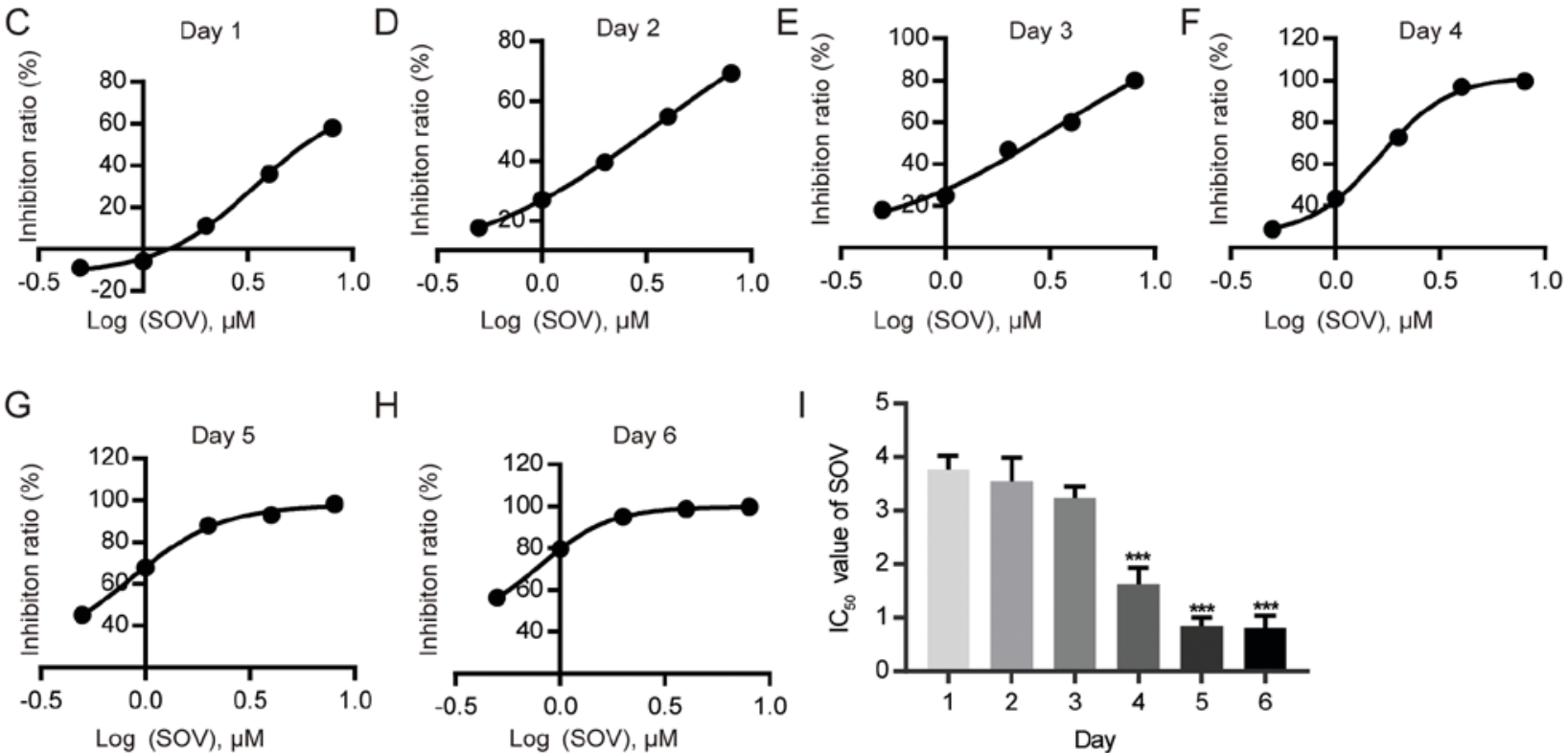

$\mathrm{H}$
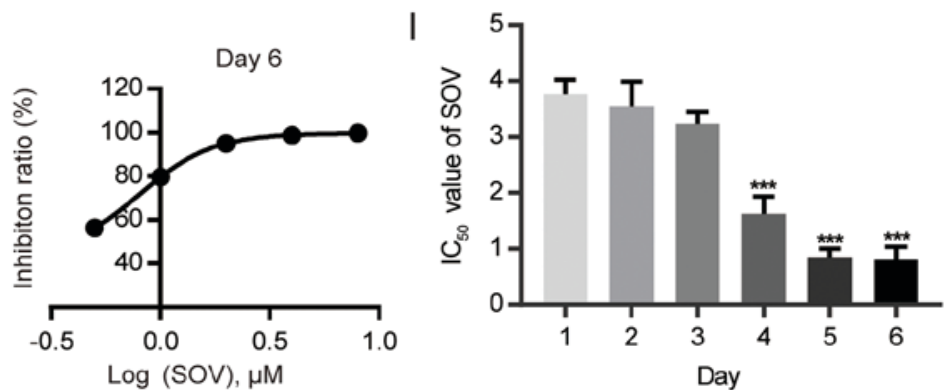

Figure 1. SOV inhibits $8505 \mathrm{C}$ cell growth in a dose- and time-dependent manner. (A and B) Viability index of $8505 \mathrm{C}$ cells treated with increasing concentrations of SOV for 1-6 days was determined using the Cell Counting kit- 8 assay. ${ }^{*} \mathrm{P}<0.05,{ }^{* *} \mathrm{P}<0.01,{ }^{* * *} \mathrm{P}<0.001 \mathrm{vs}$. the control $(0 \mu \mathrm{M} \mathrm{SOV})$ group. $(\mathrm{C}-\mathrm{H}) \mathrm{IC}{ }_{50}$ curve following SOV treatment of $8505 \mathrm{C}$ cells for $1-6$ days. (I) $\mathrm{IC}_{50}$ values following SOV treatment of $8505 \mathrm{C}$ cells for $1-6$ days. ${ }^{* * *} \mathrm{P}<0.001$ vs. day 1 . IC $\mathrm{I}_{50}$, half maximal inhibitory concentration; SOV, sodium orthovanadate.

A fluorescence microscope was used to capture images of 400 high-power fields from the slides. The apoptosis index (\%) was calculated according to the following formula: Apoptosis index=Number of apoptotic cells/Total number of nucleated cells x100. Experiments were performed three times.

Statistical analysis. GraphPad Prism 7.0 (GraphPad Software, Inc., La Jolla, CA, USA) was used for statistical analysis. Data are expressed as the means \pm standard deviation. The differences among samples were evaluated by one-way analysis of variance followed by Dunnett's test. $\mathrm{P}<0.05$ was considered to indicate a statistically significant difference.

\section{Results}

Inhibitory effect of SOV on 8505 C cell viability. The $8505 \mathrm{C}$ cell line was cultured with various concentrations of SOV $(0.5,1,2,4$ and $8 \mu \mathrm{M})$ or without SOV (control group) for 1-6 days. The cell survival rate was determined using the CCK-8 kit (Fig. 1A). SOV inhibited the viability of $8505 \mathrm{C}$ cells, and exhibited a stronger effect at higher concentrations (Fig. 1B). The $\mathrm{IC}_{50}$ values of SOV for $8505 \mathrm{C}$ growth were 3.76, $3.55,3.23,1.62,0.85$ and $0.80 \mu \mathrm{M}$ on days $1-6$, respectively (Fig. 1C-I). The mean $\mathrm{IC}_{50}$ was $2.30 \mu \mathrm{M}$.

SOV inhibits the clonogenic survival of $8505 \mathrm{C}$ cells. The effects of SOV on the clonogenic survival of $8505 \mathrm{C}$ cells were evaluated using colony formation assays. The $8505 \mathrm{C}$ cells were exposed to increasing concentrations of $\operatorname{SOV}(0.5,1$, 2, 4 and $8 \mu \mathrm{M}$ ) or culture medium for 14 days. A decrease in the number of ATC colonies following SOV treatment was observed in a concentration-dependent manner (Fig. 2A and $\mathrm{B}$ ). Concentrations of $\mathrm{SOV} \geq 1 \mu \mathrm{M}$ inhibited $>50 \%$ of $8505 \mathrm{C}$ cell colony formation compared with in the control group $(\mathrm{P}<0.01)$, and $8 \mu \mathrm{M} \mathrm{SOV}$ inhibited $98 \%$ of the colony formation $(\mathrm{P}<0.001)$.

SOV induces $G_{2} / M$ cell cycle arrest in $8505 C$ cells. In order to explore the anti-proliferative mechanism of SOV, 8505C cell cycle progression was assessed following treatment with SOV. 
A

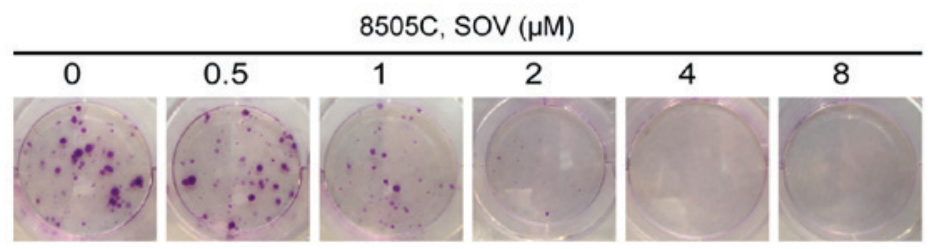

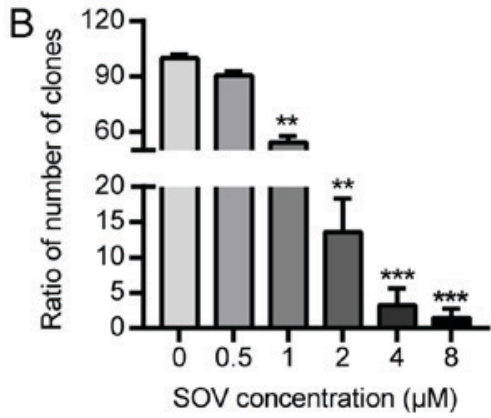

Figure 2. Colony formation of $8505 \mathrm{C}$ cells following SOV treatment for 14 days. (A) Colonies were stained with $3 \%$ crystal violet. (B) Rate of colony formation in response to each SOV concentration compared to that in the control group. ${ }^{* *} \mathrm{P}<0.01,{ }^{* * *} \mathrm{P}<0.001$ vs. the control $(0 \mu \mathrm{M}$ SOV) group. SOV, sodium orthovanadate.

Briefly, $8505 \mathrm{C}$ cells were cultured in the presence of 0,2 or $4 \mu \mathrm{M}$ SOV, according to the mean $\mathrm{IC}_{50}$ for $48 \mathrm{~h}$. Flow cytometric analysis revealed that $\mathrm{SOV}$ blocked the progression of $8505 \mathrm{C}$ cells beyond the $\mathrm{G}_{2} / \mathrm{M}$ phase (Fig. $3 \mathrm{~A}$ and $\mathrm{B}$ ). Treatment with $4 \mu \mathrm{M}$ SOV resulted in the accumulation of $40 \%$ of cells in the $\mathrm{G}_{2} / \mathrm{M}$ phase, whereas only $10 \%$ of cells in the control group were in the $\mathrm{G}_{2} / \mathrm{M}$ phase $(\mathrm{P}<0.001)$. These data suggested that $\mathrm{SOV}$ may lead to $\mathrm{G}_{2} / \mathrm{M}$ phase arrest in $8505 \mathrm{C}$ cells.

SOV induces apoptosis of $8505 \mathrm{C}$ cells. Following treatment with SOV for $48 \mathrm{~h}$, the apoptotic rate of $8505 \mathrm{C}$ cells treated with SOV was significantly higher than that of the control group $(\mathrm{P}<0.01$, Fig. $4 \mathrm{~A}$ and $\mathrm{B})$. Treatment with $2 \mu \mathrm{M} \mathrm{SOV}$ for $48 \mathrm{~h}$ increased the percentage of apoptotic $8505 \mathrm{C}$ cells to $20 \%$, and $4 \mu \mathrm{M}$ SOV resulted in $\sim 40 \%$ apoptotic cells. These data suggested that SOV may induce $8505 \mathrm{C}$ cell apoptosis in a concentration-dependent manner.

SOV diminishes the $\triangle \psi m$ of $8505 C$ cells. The effects of SOV on $\Delta \psi \mathrm{m}$ were then assessed. The $8505 \mathrm{C}$ cells treated with 2 or $4 \mu \mathrm{M}$ SOV for $48 \mathrm{~h}$ exhibited lower red and higher green fluorescence than those of the control group, and $\Delta \psi \mathrm{m}$ alterations were observed in a concentration-dependent manner (Fig. 5A). In addition, 60 and $80 \%$ of cells exhibited green fluorescence (early apoptotic) in the groups treated with 2 and $4 \mu \mathrm{M}$, respectively (Fig. 5B).

SOV inhibits xenograft tumor growth and induces apoptosis in vivo. Following treatment of nude mice with SOV, or PBS as a control, tumor volume was calculated by assessing tumor diameter weekly. The results demonstrated that the tumor volume in the SOV group was smaller than that in the control group from the first week, and the difference in tumor volume between groups was positively associated with treatment duration. In the two SOV intervention groups, the tumor volume in the high-concentration group $(10 \mathrm{mg} / \mathrm{kg}$ ) was smaller than that in the low-concentration group ( $5 \mathrm{mg} / \mathrm{kg}$; $\mathrm{P}<0.05$, Fig. $6 \mathrm{~A}$ and $\mathrm{B}$ ). This suggested that treatment with SOV significantly inhibited tumor growth compared to that in the control group. Therefore, SOV may inhibit the growth of ectopic ATC.

In order to detect $8505 \mathrm{C}$ cell proliferation after SOV or PBS treatment, the expression of the proliferative biomarker protein Ki-67 was detected by immunohistochemistry. The results revealed that the expression of $\mathrm{Ki}-67$ in the tumor tissues of the SOV group was significantly lower than that in the control group. In addition, Ki-67 expression in the high-SOV group $(10 \mathrm{mg} / \mathrm{kg}$ ) was significantly lower than that in the low-SOV group $(5 \mathrm{mg} / \mathrm{kg} ; \mathrm{P}<0.05$, Fig. $6 \mathrm{C}$ and $\mathrm{D})$. In order to assess the apoptosis of $8505 \mathrm{C}$ cells, an in situ TUNEL assay was performed. The results demonstrated that the number of apoptotic cells treated with SOV was higher than that in the control group, and was positively associated with SOV concentration (Fig. 6E and F). These results revealed that SOV inhibited the proliferation and promoted the apoptosis of $8505 \mathrm{C}$ cells in vivo.

\section{Discussion}

ATC is the most malignant type of thyroid cancer, and is characterized by early metastasis and invasion of local organs. Surgical treatment commonly fails as a radical treatment. To the best of our knowledge, there is currently no efficient chemotherapeutic drug able to control ATC development. It is therefore crucial to develop novel treatments. In the present study, SOV promoted the apoptosis of $8505 \mathrm{C}$ cells, leading to $\mathrm{G}_{2} / \mathrm{M}$ phase cell cycle arrest. These results provided a novel option for the treatment of undifferentiated thyroid cancer.

Previous studies have revealed that vanadium salts can inhibit the progression of various tumors and trigger apoptosis of numerous cancer cells, including neuroblastoma (SH-SY5Y cells) (13), lung cancer (A549 cells) (14), renal cancer (HTB44 cells) (14), prostate cancer (DU145 and PC-3 cells) $(14,15)$, bladder cancer (T24 cells) (16), liver cancer (HepG2, SK-Hep-1, Hep3B and h35-19 cells) $(17,18)$ and monocytic leukemia (U937 cells) (21). Nevertheless, some studies revealed that vanadium salts can promote tumor progression. For instance, Afshari et al demonstrated that vanadium salts cause Syrian hamster embryo cells to escape senescence and become immortalized at a low frequency, eventually leading to the occurrence of tumors (22). In addition, Hwang et al reported that vanadium salts lead to tumor formation by activating hypoxia-inducible factor 1 (23). The present results revealed that a low concentration of $\mathrm{SOV}(0.5 \mu \mathrm{M})$ administered over a short period of time $(24 \mathrm{~h})$ stimulated $8505 \mathrm{C}$ cell growth; however, increases in the concentration and the treatment period inhibited $8505 \mathrm{C}$ cell growth in a concentration- and time-dependent manner. The $\mathrm{IC}_{50}$ values of $\mathrm{SOV}$ for $8505 \mathrm{C}$ growth were $3.76,3.55,3.23,1.62,0.85$ and $0.80 \mu \mathrm{M}$ on 
A

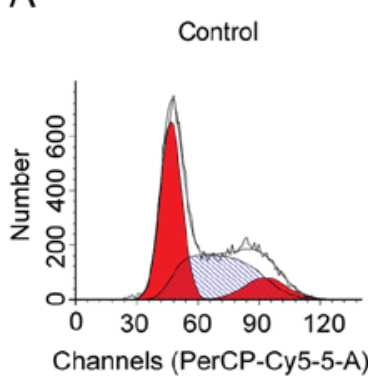

SOV $(2 \mu \mathrm{M})$

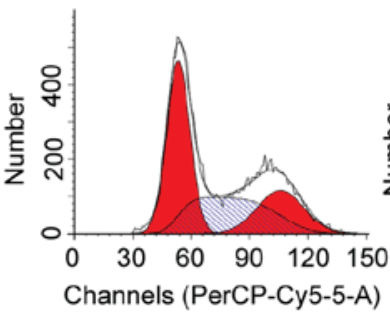

SOV $(4 \mu M)$

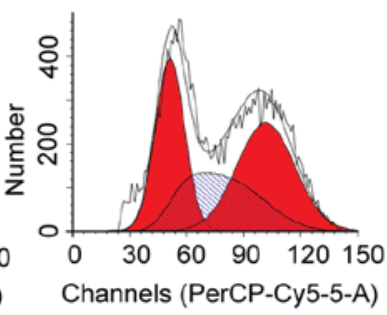

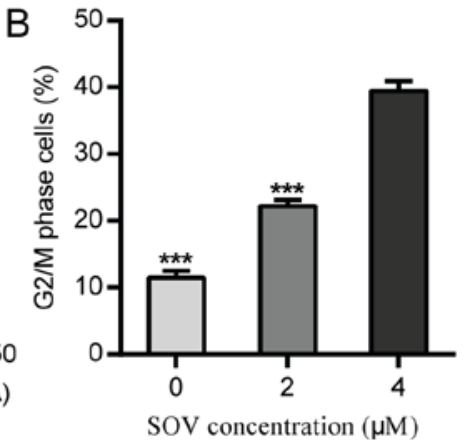

Figure 3. SOV induces $\mathrm{G}_{2} / \mathrm{M}$ cell cycle arrest in $8505 \mathrm{C}$ cells. (A) DNA content and cell cycle analysis of $8505 \mathrm{C}$ cells treated with SOV at 0,2 or $4 \mu \mathrm{M}$ for $48 \mathrm{~h}$. (B) Cell cycle distribution revealed that $8505 \mathrm{C}$ treated with $\mathrm{SOV}$ cells exhibited $\mathrm{G}_{2} / \mathrm{M}_{\text {phase }}$ arrest in a concentration-dependent manner. ${ }^{* * *} \mathrm{P}<0.001$ vs. the control (0 $\mu \mathrm{M}$ SOV) group. SOV, sodium orthovanadate.

A

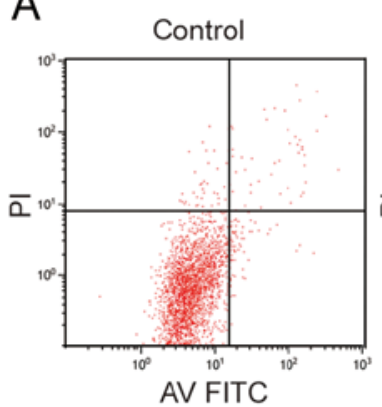

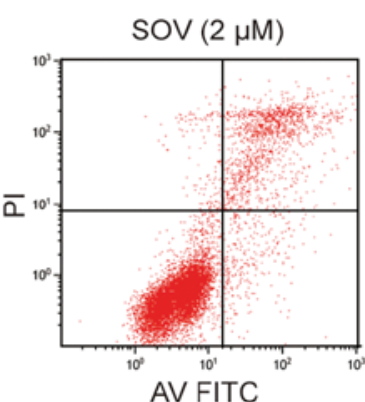

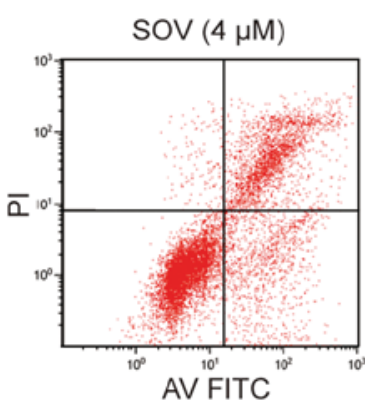

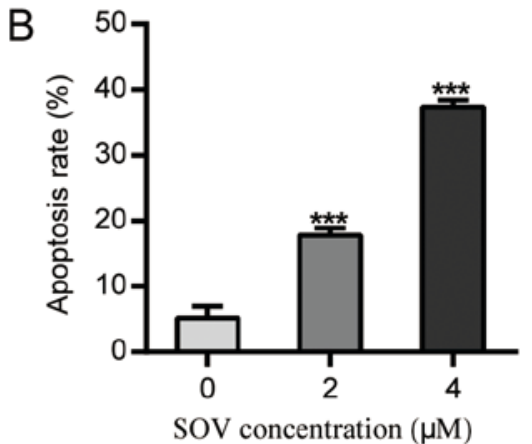

SOV concentration $(\mu \mathrm{M})$

Figure 4. SOV induces apoptosis of $8505 \mathrm{C}$ cells. $8505 \mathrm{C}$ cells were treated with 0,2 or $4 \mu \mathrm{M}$ SOV for $48 \mathrm{~h}$. (A) Flow cytometry was performed to observe apoptotic rates. (B) Representative histograms of apoptotic rates of $8505 \mathrm{C}$ cells. ${ }^{* * *} \mathrm{P}<0.001$ vs. the control $(0 \mu \mathrm{M}$ SOV) group. FITC, fluorescein isothiocyanate; PI, propidium iodide; SOV, sodium orthovanadate.

A

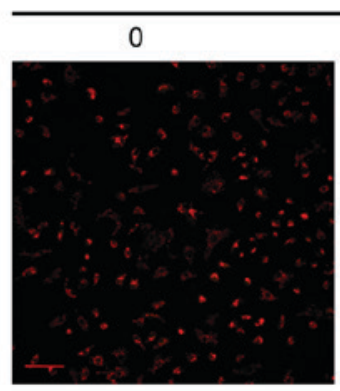

SOV concentration $(\mu \mathrm{M})$

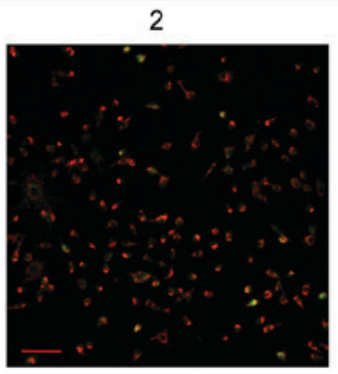

B

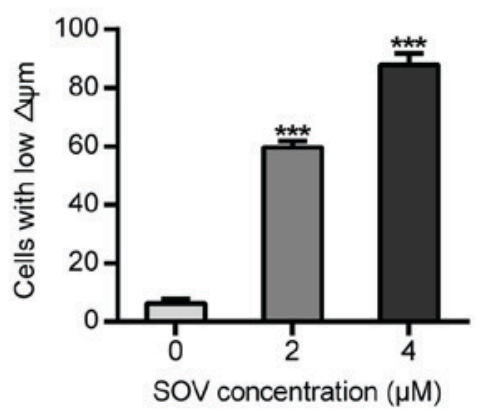

Figure 5. Alterations in $\Delta \psi \mathrm{m}$ of $8505 \mathrm{C}$ cells in vitro. (A) $8505 \mathrm{C}$ cells treated with 0,2 or $4 \mu \mathrm{M}$ SOV for $48 \mathrm{~h}$ prior to staining with JC-1. $\Delta \psi \mathrm{m}$ was detected by fluorescence microscopy. When $\Delta \psi \mathrm{m}$ was high, JC-1 accumulated in the mitochondrial matrix as a polymer (J-aggregates), producing red fluorescence; when $\Delta \psi \mathrm{m}$ was low, JC-1 accumulated in the mitochondrial matrix as JC-1 monomers (monomer), producing green fluorescence. (B) Representative histograms of $8505 \mathrm{C}$ cell labeling with JC-1 dye. Scale bar, $100 \mu \mathrm{m}$. ${ }^{* * *} \mathrm{P}<0.001$ vs. the control $(0 \mu \mathrm{M}$ SOV $)$ group. SOV, sodium orthovanadate; $\Delta \psi \mathrm{m}$, mitochondrial membrane potential.

days 1-6, respectively. In addition, Kordowiak et al indicated that vanadium salts at low concentrations $(0.5-1 \mu \mathrm{M})$ improve the morphology and viability of H35-19 rat hepatoma cells, whereas higher concentrations $(2.5 \mu \mathrm{M})$ of vanadium act as a cellular growth inhibitor (18). In addition to cell growth, cell clone formation also decreased with increasing concentration. In the present study, SOV had a dual effect on 8505C cells: Low concentrations may promote cell growth and high concentrations inhibited tumor cell growth. This area requires further investigation, and lower SOV concentrations and treatments duration should be tested.

Induction of cell cycle arrest can inhibit cell growth. In the present study, SOV induced tumor cell cycle arrest, resulting in the majority of cells being arrested in the $G_{2} / M$ phase. Liu et al also reported that vanadium salts induce $\mathrm{G}_{2} / \mathrm{M}$-phase arrest by reactive oxygen species-mediated degradation of cell division cycle $25 \mathrm{C}$ in PC-3 cells (15). Wu et al reported that vanadium salts increase the phosphorylation of cyclin B1 at 
A

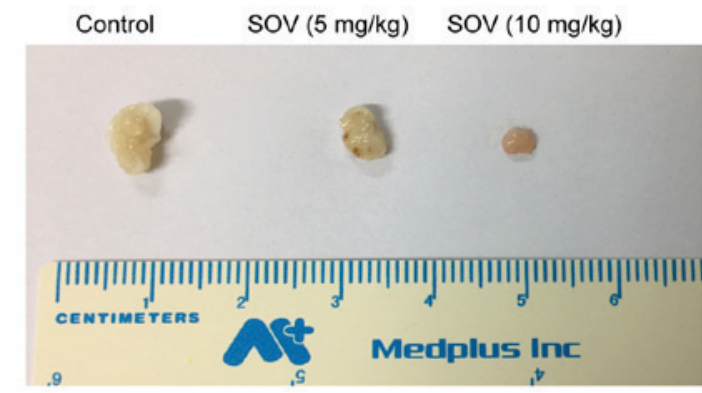

C
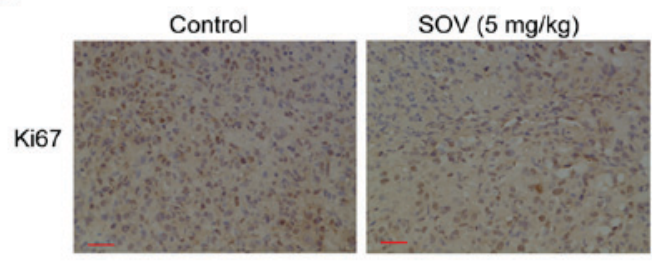

E

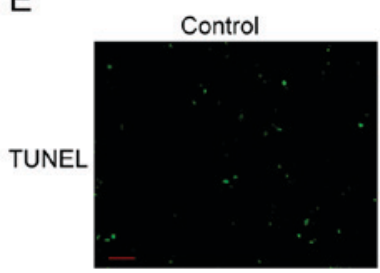

$\operatorname{SOV}(5 \mathrm{mg} / \mathrm{kg})$

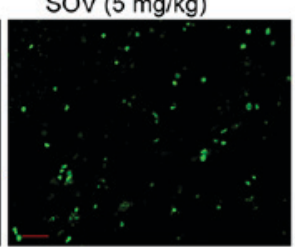

$\operatorname{SoV}(10 \mathrm{mg} / \mathrm{kg})$

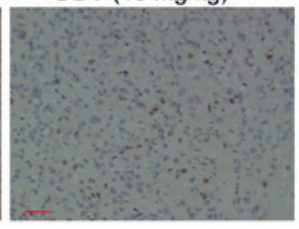

$\operatorname{soV}(10 \mathrm{mg} / \mathrm{kg})$
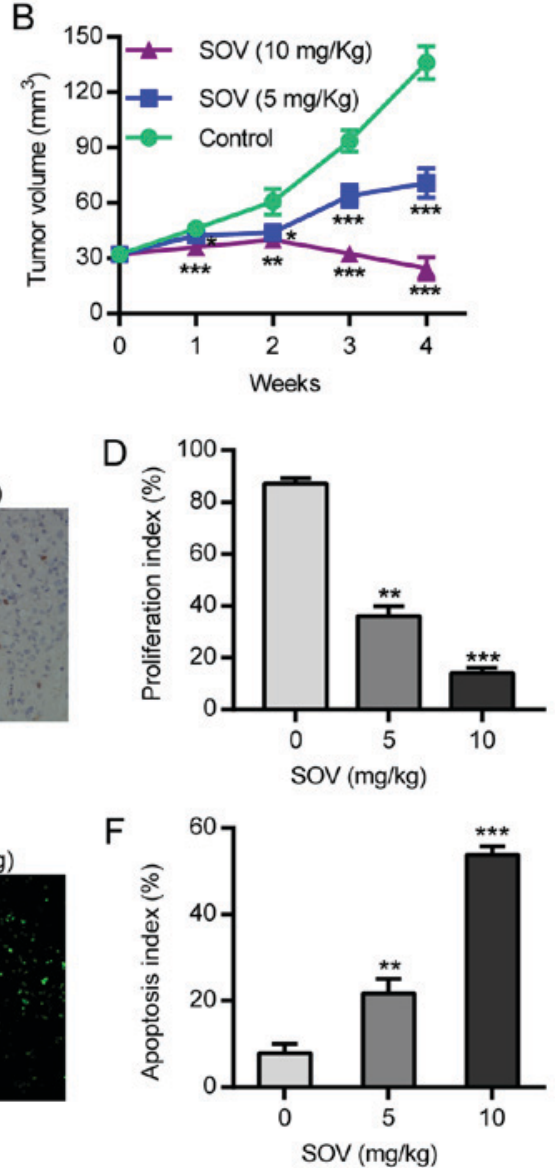

Figure 6. SOV inhibits tumor growth and induces apoptosis in vivo. An aliquot of $1 \times 10^{6} 8505 \mathrm{C}$ cells was injected subcutaneously into the flanks of female nude NU/NU mice; when tumors grew to $\sim 4 \mathrm{~mm}$ diameter, animals were randomly divided into three groups and treated with 5 , $10 \mathrm{mg} / \mathrm{kg} \mathrm{SOV}$, or PBS. After 4 weeks of treatment, tumors were harvested. (A) $8505 \mathrm{C}$ xenograft tumor volumes in the different groups. (B) Alterations in $8505 \mathrm{C}$ xenograft tumor volume over the 4-week treatment period. (C and D) Tumor sections were stained with an anti-Ki-67 antibody to detect proliferating cells. (E and F) Tumor sections were stained with TUNEL agent to visualize apoptotic cells. Scale bar, $50 \mu \mathrm{m} .{ }^{*} \mathrm{P}<0.05,{ }^{* *} \mathrm{P}<0.01$, ${ }^{* * * *} \mathrm{P}<0.001 \mathrm{vs}$. the control (PBS) group. SOV, sodium orthovanadate; TUNEL, terminal deoxynucleotidyl transferase dUTP nick end labeling.

Thr161 and reduce its phosphorylation at Tyr15, leading to $\mathrm{G}_{2} / \mathrm{M}$ phase arrest in HepG2, SK-Hep-1 and Hep3B cells (17). Nevertheless, Zhang et al reported that vanadate is also able to induce $S$ phase arrest via p53- and p21-dependent pathways (24). In the present study, SOV induced $8505 \mathrm{C}$ cell cycle arrest in the $\mathrm{G}_{2} / \mathrm{M}$ phase in a concentration-dependent manner. Treatment with $4 \mu \mathrm{M}$ SOV resulted in the accumulation of $40 \%$ of cells in $\mathrm{G} 2 / \mathrm{M}$ phase, whereas only $10 \%$ of cells in the control group were in $\mathrm{G}_{2} / \mathrm{M}$ phase.

Apoptosis induction is one of the main effects of antitumor drugs. Numerous studies have demonstrated that vanadium salts can regulate apoptosis in different ways. They can suppress (25), enhance (26-28) or induce (29) apoptosis. Morita et al revealed that SOV inhibits p53-mediated apoptosis (30), whereas Günther et al reported that SOV potentiates apoptosis induction, possibly via a p53-independent mechanism (16). In addition to p53, apoptosis is closely associated with protein levels of B-cell lymphoma 2 (Bcl-2) and Bcl-extra large (Bcl-xl) (16). Bcl-2 is located in mitochondrial membranes and endoplasmic reticulum, and regulates apoptosis. The present study demonstrated that SOV induced apoptosis of $8505 \mathrm{C}$ cells in a concentration-dependent manner. In addition, SOV reduced $\Delta \psi \mathrm{m}$ of $8505 \mathrm{C}$ cells, which suggested that SOV induced cell apoptosis via the mitochondrial pathway (31).
Animal models are essential for studying the effects of chemotherapeutic drugs, as their effects on complex systems, including host metabolism, host defense and the endocrine system, must be considered in order to evaluate their safety and efficacy (32). Previous studies have demonstrated that orthovanadate exerts significant anticancer effects on tumor-bearing mice. Günther et al reported that vanadium salts inhibit Ehrlich ascites carcinoma proliferation and enhance mice survival, and observed that vanadium combined with ascorbate at a pharmacological dose has an even better anticancer effect (16). Wu et al demonstrated that SOV treatment results in a clear suppression of tumor growth in a mouse orthotopic transplantation model of hepatocellular carcinoma (17). In addition, it has been indicated that vanadium administration suppresses colon carcinogenesis in rats (33). The antitumor effects of SOV on ATC xenografts in vivo were investigated in the present study. The results exhibited that SOV markedly suppressed tumor growth in mice xenograft models of $8505 \mathrm{C}$ cells. In addition, tumor growth inhibition was stronger at higher SOV concentrations $(10 \mathrm{mg} / \mathrm{kg})$ than at lower concentrations $(5 \mathrm{mg} / \mathrm{kg})$. Furthermore, via the detection of the biomarker Ki-67, results revealed that SOV significantly inhibited tumor proliferation, and TUNEL assays indicated that SOV also significantly induced tumor cell apoptosis. 
A previous study has revealed that SOV acts as an antitumor agent and promotes cell death by inhibiting autophagy (17). To the best of our knowledge, the antitumor mechanism of SOV is currently not well understood, and mostly involves protein phosphatase inhibition and increases in phosphodiesterase and protein kinase activity, which are involved in cell growth and development, DNA damage, regulation of genes and proteins, and oxidative stress.

The present study has some limitations. It was not possible to elucidate the underlying mechanism of the antitumor effects of SOV, and the expression of apoptosis-associated proteins induced by cell cycle arrest were not assessed. Furthermore, the state of and changes in p53 in $8505 \mathrm{C}$ cells were not detected in the pathogenesis of apoptosis. Subsequently, the association between SOV-induced apoptosis and SOV-induced p53 regulation was not investigated. Finally, no attempt was made to elucidate the reason why low concentrations of SOV promoted $8505 \mathrm{C}$ cell growth. It may therefore be important to further investigate this point by decreasing duration and concentration of SOV treatment.

In conclusion, the present study revealed that SOV had some important anticancer effects in ATC, including the inhibition of tumor cell viability, induction of $\mathrm{G}_{2} / \mathrm{M}$ cell cycle arrest and promotion of apoptosis. These results provided a basis for further investigations on the development of novel SOV-based chemotherapeutic drugs for the treatment of undifferentiated thyroid cancer.

\section{Acknowledgements}

The authors would like to thank Dr Shangha Pan (Central Laboratory, The First Affiliated Hospital of Harbin Medical University, Harbin, China) for his assistance with the experiments.

\section{Funding}

This study was supported by the China Medical Board (grant no. 08-894).

\section{Availability of data and materials}

The datasets used and/or analyzed during the current study are available from the corresponding author on reasonable request.

\section{Authors' contributions}

QY, HJ and WD conceived and designed the study. QY, WJ, DL, MG, KL, and LD performed the experiments. CW and QY analyzed the data. QY wrote the manuscript.

\section{Ethics approval and consent to participate}

All surgical procedures and animal care protocols were approved by the Ethics Committee of the First Affiliated Hospital of Harbin Medical University (Harbin, China).

\section{Patient consent for publication}

Not applicable.

\section{Competing interests}

The authors declare that they have no competing interests.

\section{References}

1. Nagaiah G, Hossain A, Mooney CJ, Parmentier J and Remick SC: Anaplastic thyroid cancer: A review of epidemiology, pathogenesis, and treatment. J Oncol 2011: 542358, 2011.

2. Davies L and Welch HG: Increasing incidence of thyroid cancer in the United States, 1973-2002. Jama 295: 2164-2167, 2006.

3. Cornett WR, Sharma AK, Day TA, Richardson MS, Hoda RS, van Heerden JA and Fernandes JK: Anaplastic thyroid carcinoma: An overview. Curr Oncol Rep 9: 152-158, 2007.

4. O'Neill JP, O'Neill B, Condron C, Walsh M and Bouchier-Hayes D: Anaplastic (undifferentiated) thyroid cancer: Improved insight and therapeutic strategy into a highly aggressive disease. J Laryngol Otol 119: 585-591, 2005.

5. Paunovic IR, Sipetic SB, Zoric GV, Diklic AD, Savic DV, Marinkovic J and Zivaljevic VR: Survival and prognostic factors of anaplastic thyroid carcinoma. Acta Chir Belg 115: 62-72, 2015.

6. Perri F, Lorenzo GD, Scarpati GD and Buonerba C: Anaplastic thyroid carcinoma: A comprehensive review of current and future therapeutic options. World J Clin Oncol 2: 150-157, 2011.

7. Kim SH, Kang JG, Kim CS, Ihm SH, Choi MG, Yoo HJ and Lee SJ: Apigenin induces c-Myc-mediated apoptosis in FRO anaplastic thyroid carcinoma cells. Mol Cell Endocrinol 369: 130-139, 2013.

8. $\mathrm{Yu} \mathrm{XM}$, Jaskulasztul $\mathrm{R}$, Ahmed $\mathrm{K}$, Harrison AD, Kunnimalaiyaan $\mathrm{M}$ and Chen $\mathrm{H}$ : Resveratrol induces differentiation markers expression in anaplastic thyroid carcinoma via activation of Notch1 signaling and suppresses cell growth. Mol Cancer Ther 12: 1276-1287, 2013.

9. Che H, Guo H, Si X, You Q and Lou W: Additive effect by combination of Akt inhibitor, MK-2206, and PDGFR inhibitor, tyrphostin AG 1296, in suppressing anaplastic thyroid carcinoma cell viability and motility. Onco Ther 7: 425-432, 2014.

10. Reeb AN, Li W, Sewell W, Marlow LA, Tun HW, Smalliridge RC, Copland JA, Spradling K, Chernock R and Lin RY: S100A8 is a novel therapeutic target for anaplastic thyroid carcinoma. J Clin Endocrinol Metab 100: 232-242, 2015.

11. Alonso A, Sasin J, Bottini N, Friedberg I, Friedberg I, Osterman A, Godzik A, Hunter T, Dixon J and Mustelin T: Protein tyrosine phosphatases in the human genome. Cell 117: 699-711, 2004.

12. Korbecki J, Baranowska-Bosiacka I, Gutowska I and Chlubek D: Biochemical and medical importance of vanadium compounds. Acta Biochim Pol 59: 195-200, 2012.

13. Tian X, Fan J, Hou W, Bai S, Ao Q and Tong H: Sodium orthovanadate induces the apoptosis of SH-SY5Y cells by inhibiting PIWIL2. Mol Med Rep 13: 874-880, 2016.

14. Klein A, Holko P, Ligeza J and Kordowiak AM: Sodium orthovanadate affects growth of some human epithelial cancer cells (A549, HTB44, DU145). Folia Biol (Krakow) 56: 115-121, 2008.

15. Liu TT, Liu YJ, Wang Q, Yang XG and Wang K: Reactiveoxygen-species-mediated Cdc25C degradation results in differential antiproliferative activities of vanadate, tungstate, and molybdate in the PC-3 human prostate cancer cell line. J Biol Inorg Chem 17: 311-320, 2012.

16. Günther TM, Kviecinski MR, Baron CC, Felipe KB, Farias MS, da Silva FO, Bücker NC, Pich CT, Ferreira EA, Wilhelm Filho D, et al: Sodium orthovanadate associated with pharmacological doses of ascorbate causes an increased generation of ROS in tumor cells that inhibits proliferation and triggers apoptosis. Biochem Biophys Res Commun 430: 883-888, 2013.

17. Wu Y, Ma Y, Xu Z, Wang D, Zhao B, Pan H, Wang J, Xu D, Zhao X, Pan S, et al: Sodium orthovanadate inhibits growth of human hepatocellular carcinoma cells in vitro and in an orthotopic model in vivo. Cancer Lett 351: 108-116, 2014.

18. Kordowiak AM, Klein A, Goc A and Dabroś W: Comparison of the effect of VOSO4, $\mathrm{Na} 3 \mathrm{VO} 4$ and $\mathrm{NaVO} 3$ on proliferation, viability and morphology of H35-19 rat hepatoma cell line. Pol J Pathol 58: 51-57, 2007.

19. Reed LJ and Muench H: A simple method of estimating fifty percent endpoints. Am J Hyg 27: 1938.

20. Ostrowski J, Woszczyński M, Kowalczyk P, Trzeciak L, Hennig E and Bomsztyk K: Treatment of mice with EGF and orthovanadate activates cytoplasmic and nuclear MAPK, p70S6k, and p90rsk in the liver. J Hepatol 32: 965-974, 2000. 
21. Choi YJ, Lim SY, Woo JH, Kim YH, Kwon YK, Suh SI, Lee SH, Choi WY, Kim JG, Lee IS, et al: Sodium orthovanadate potentiates EGCG-induced apoptosis that is dependent on the ERK pathway. Biochem Biophys Res Commun 305: 176-185, 2003.

22. Afshari CA, Kodama S, Bivins HM, Willard TB, Fujiki H and Barrett JC: Induction of neoplastic progression in Syrian hamster embryo cells treated with protein phosphatase inhibitors. Cancer Res 53: 1777-1782, 1993.

23. Hwang JT, Lee M, Jung SN, Lee HJ, Kang I, Kim SS and Ha J: AMP-activated protein kinase activity is required for vanadate-induced hypoxia-inducible factor 1alpha expression in DU145 cells. Carcinogenesis 25: 2497, 2004.

24. Zhang Z, Huang C, Li J and Shi X: Vanadate-induced cell growth arrest is p53-dependent through activation of p21 in C141 cells. J Inorg Biochem 89: 142-148, 2002.

25. Morita A, Zhu J, Suzuki N, Enomoto A, Matsumoto Y, Tomita M, Suzuki T, Ohtomo K and Hosoi Y: Sodium orthovanadate suppresses DNA damage-induced caspase activation and apoptosis by inactivating p53. Cell Death Differ 13: 499-511, 2006.

26. Gamero AM and Larner AC: Vanadate facilitates interferon alpha-mediated apoptosis that is dependent on the Jak/Stat pathway. J Bioll Chem 276: 13547-13553, 2001.

27. Stewart C, Mihai R and Holly JM: Increased tyrosine kinase activity but not calcium mobilization is required for ceramide-induced apoptosis. Exp Cell Res 250: 329-338, 1999.

28. Guo YL, Baysal K, Kang B, Yang LJ and Williamson JR: Correlation between sustained c-Jun N-terminal protein Kinase activation and apoptosis induced by tumor necrosis factor- $\alpha$ in rat mesangial cells. J Biol Chem 273: 4027-4034, 1998.
29. Figiel I and Kaczmarek L: Orthovanadate induces cell death in rat dentate gyrus primary culture. Neuroreport 8: 2465-2470, 1997.

30. Morita A, Yamamoto S, Wang B, Tanaka K, Suzuki N, Aoki S, Ito A, Nanao T, Ohya S, Yoshino M, et al: Sodium orthovanadate inhibits p53-mediated apoptosis. Cancer Res 70: 257-265, 2010.

31. Cossarizza A, Franceschi C, Monti D, Salvioli S, Bellesia E, Rivabene R, Biondo L, Rainaldi G, Tinari A and Malorni W: Protective effect of $\mathrm{N}$-acetylcysteine in tumor necrosis factor-alpha-induced apoptosis in U937 cells: The role of mitochondria. Exp Cell Res 220: 232-240, 1995.

32. Ray RS, Ghosh B, Rana A and Chatterjee M: Suppression of cell proliferation, induction of apoptosis and cell cycle arrest: Chemopreventive activity of vanadium in vivo and in vitro. Int J Cancer 120: 13-23, 2007.

33. Kanna P, Mahendrakumar CB, Chakraborty T, Hemalatha $\mathrm{P}$, Banerjee P and Chatterjee M: Effect of vanadium on colonic aberrant crypt loci induced in rats by 1,2 dimethyl hydrazine. World J Gastroenterol 9: 1020-1027, 2003.

(i) (9) This work is licensed under a Creative Commons

(c) Attribution-NonCommercial-NoDerivatives 4.0 International (CC BY-NC-ND 4.0) License. 